\title{
Restricted Phosphorus Fertilization Increases the Betacyanin Concentration and Red Foliage Coloration of Alternanthera
}

\author{
Josh B. Henry ${ }^{1}$, Penelope Perkins-Veazie, Ingram McCall, and Brian E. Whipker \\ Department of Horticultural Science, North Carolina State University, Box 7609, Raleigh, NC 27695
}

\begin{abstract}
AdDITIONAL INDEX wORDs. anthocyanin, betalain, floriculture, nutrition, phosphate, pigments
Abstract. Phosphorus (P) deficiency commonly results in the development of red-to-purple coloration in plant foliage, typically attributed to anthocyanins. Betacyanins are a red pigment found in some plant species that do not produce anthocyanins, including Alternanthera sp. This study was conducted to investigate the effects of $P$ nutrition on the betacyanin concentration and subsequent foliar coloration of 'Purple Prince', 'Brazilian Red Hots', and 'Little Ruby' alternanthera (Alternanthera brasiliana). The purpose of this study was to determine whether $P$ fertilization management could enhance the coloration and aesthetic appeal of alternanthera. Custom fertilizers provided $P$ concentrations of $0,2.5,5,10$, and $20 \mathrm{mg} \cdot \mathrm{L}^{-1} \mathrm{P}$. One-half of the plants from each $P$ concentration were restricted to 0 $\mathrm{mg} \cdot \mathrm{L}^{-1} \mathrm{P} 1$ month after transplant to determine whether adequate size could be attained before withholding $P$. Differences in $P$ response were observed among cultivars for hue, betacyanin content, and plant size. Concentrations $\leq 5 \mathrm{mg} \cdot \mathrm{L}^{-1} \mathrm{P}$ resulted in plants that were more compact in terms of plant height and diameter, had deeper red foliage coloration, and greater foliar betacyanins compared with plants grown with greater $P$ concentrations. Plants initially grown with 5 or $10 \mathrm{mg} \cdot \mathrm{L}^{-1} \mathrm{P}$ attained marketable size before $\mathrm{P}$ restriction and developed more red pigmentation compared with plants grown with $P$ for the remaining duration of the study. Regression analysis demonstrated height was maximized with 3 to $8 \mathrm{mg} \cdot \mathrm{L}^{-1} P$, diameter with 4.1 to $8.4 \mathrm{mg} \cdot \mathrm{L}^{-1} \mathrm{P}$, and branching with $10.0 \mathrm{mg} \cdot \mathrm{L}^{-1} \mathrm{P}$. Foliar betacyanin concentrations were greatest in plants grown without $P$, reaching $269 \mathrm{mg} / 100 \mathrm{~g}$ fresh weight, whereas plants grown with 10 or $20 \mathrm{mg} \cdot \mathrm{L}^{-1} \mathrm{P}$ were $95 \%$ less (averaged $\approx 13 \mathrm{mg} / 100 \mathrm{~g}$ fresh weight). This study demonstrates that $P$ restriction can benefit the aesthetic appeal of alternanthera and provides the first confirmation that $P$ nutrition is associated with betacyanin accumulation.
\end{abstract}

Increased red foliage pigmentation is one of the primary symptoms associated with phosphorus deficiency. This pigmentation typically is attributed to foliar anthocyanins, a common source of red pigments found in plants (Sarker and Karmoker, 2011). Anthocyanins play a variety of roles in plants, including antioxidation, camouflage, free radical scavenging, herbivory and pathogen defense, insect mimicry, photoprotection, pollinator attraction, signal transduction, and water relations (Hatier and Gould, 2009; Henry et al., 2012; Hernández and Munné-Bosch, 2015; Lev-Yadun and Gould, 2009). Upregulation of anthocyanin biosynthesis occurs due to excess light, ozone, and pollutants; wounding, infection, insect feeding, and extreme temperatures; plus limited water, nitrogen $(\mathrm{N})$, and $\mathrm{P}$ availability (Hatier and Gould, 2009). It is believed because P deficiency stress limits plant growth, certain molecules and precursors normally used for primary metabolic processes, such as phenylalanine, sucrose, mannitol, and mannose, are instead used for secondary metabolic processes such as anthocyanin synthesis (Deroles, 2009). Inhibited growth due to limited cell division and DNA synthesis increases the activity of several key enzymes in the anthocyanin biosynthetic pathway. These enzymes include

Received for publication 29 Mar. 2019. Accepted for publication 9 May 2019. We are grateful for funding support provided by the Fred C. Gloeckner Foundation, the U.S. Department of Agriculture Floriculture and Nursery Research Initiative, American Floral Endowment Altman Family Scholarship, and The Garden Club of America. We would also express our gratitude to Dümmen Orange for providing cuttings, and to SunGro Horticulture for providing peat moss.

This paper is a portion of a thesis submitted by Josh B. Henry in fulfilling a degree requirement.

${ }^{1}$ Corresponding author. E-mail: josh.brady.henry@gmail.com. phenylalanine ammonia lyase, chalcone synthase, dihydroflavonol-4-reductase, and 3-deoxy-D-arabino-heptulosonate 7-phosphate synthase (Deroles, 2009; Plaxton and Carswell, 1999). These enzymes are used in the anthocyanin biosynthetic pathway and are accompanied by increased anthocyanin concentrations. Reintroduction of P transitions growth back to cell division, using excess phenylalanine and limiting anthocyanin accumulation (Chen et al., 2013; Deroles, 2009).

Several studies report low P effects on foliar anthocyanin concentration. Tomato (Solanum lycopersicum) plants grown without $\mathrm{P}$ develop anthocyanin concentrations up to five times greater than concentrations found in plants grown with adequate P fertility (Ulrychová and Sosnová, 1970). Other studies report a similar relationship between $\mathrm{P}$ fertility and anthocyanin concentrations in ajuga (Ajuga sp.), carrot (Daucus carota), chinese kale (Brassica alboglabra), grape (Vitis vinifera), maize (Zea mays), strawberry (Fragaria ananassa), and vinca (Catharanthus roseus) (Chen et al., 2013; Cobbina and Miller, 1987; Deroles, 2009; Rajendran et al., 1992). In contrast, other studies report foliar anthocyanin concentrations were not correlated with $\mathrm{P}$ availability in coleus (Plectranthus scutellarioides), a common floriculture species grown for its colorful foliage (Boldt, 2013; Henry et al., 2012). This demonstrates that although low $\mathrm{P}$ stress typically is associated with increasing anthocyanin biosynthesis, the effect is species-dependent. Although the relationship between $\mathrm{P}$ deficiency and anthocyanin production has long been established (Mengel et al., 2001; Ulrychová and Sosnová, 1970), there has been little research investigating using low $P$ fertilization concentrations to beneficially enhance pigmentation of ornamental species. 
Although anthocyanins are the most common red pigment found in plants, betalains are a class of tyrosine-derived pigments that also provide red coloration (Lev-Yadun and Gould, 2009; Polturak and Aharoni, 2018). Betacyanins are a category of betalain that cause the red pigmentation found only in plants from the order Caryophyllales and are best known for providing the color in red beet [Beta vulgaris (Tanaka et al., 2008)]. Maximum absorptivity for betacyanin pigments is between 535 and $538 \mathrm{~nm}$ (Polturak and Aharoni, 2018), whereas anthocyanins range from 496 to $557 \mathrm{~nm}$ (Giusti et al., 1999). Like anthocyanins, betacyanins are found in vacuoles of vegetative and reproductive tissues, resulting in similar coloration patterns (Brockington et al., 2011). Betalains and anthocyanins do not occur in the same species (Tanaka et al., 2008), and betalain-producing species lack the enzymes required for anthocyanin biosynthesis due to transcriptional downregulation (Brockington et al., 2011). However, members of the Caryophyllales in the Molluginaceae and Caryophyllaceae produce anthocyanins rather than betalains, suggesting the ancestors of modern betalain-producing species were once capable of producing anthocyanins (Brockington et al., 2011; Ehrendorfer, 1976). Other hypotheses suggest an ancestral member of the Caryophyllales produced both pigments (Clement and Mabry, 1996), but divergent evolution led to the mutual exclusivity observed in modern plant species.

Aside from functioning as pigments to attract pollinators, anthocyanins and betacyanins share a number of similar roles in plants, including stress response functions. Water stress increases anthocyanin (Deroles, 2009) and betacyanin accumulation (Nakashima et al., 2011), which consequently induces several antioxidant and photoprotective responses. For instance, betacyanins contribute to photoprotection in response to water stress via reduced excitation pressure on photosystem II (Nakashima et al., 2011). An increase in betacyanin accumulation is observed in ice plant (Mesembryanthemum crystallinum) cells when exposed to high ultraviolet A radiation (Vogt et al., 1999). Similar increases in betacyanin biosynthesis occur in response to wounding or bacterial infection in the foliage of red beet (Sepúlveda-Jiménez et al., 2004). Betacyanins also serve as reactive oxygen species (ROS) scavengers and help to mitigate the effects of ROS-induced photoinhibition in the plant Suaeda japonica (Hayakawa and Agarie, 2010). Furthermore, increases in betacyanin biosynthesis occur in response to ROS, cobalt, molybdenum, iron, and copper (Jain and Gould, 2015a; Sepúlveda-Jiménez et al., 2004). Other roles betacyanins serve in plants include sodium compartmentalization, deterring herbivory, and heavy metal tolerance (Jain and Gould, 2015a). An extensive diversity of functions and physiological responses have been reported for betalains, but there remains no mention of the effect of $\mathrm{P}$ mineral nutrition in the current literature.

Further research is necessary to determine the effects of plant mineral nutrition and other environmental factors on betacyanin biosynthesis and accumulation. In addition, few studies consider betacyanin pigmentation from an ornamental standpoint. Many floricultural species produce betalains and are grown for the aesthetic appeal of the vibrant red-to-purple coloration displayed in leaves and flowers. Some betalainproducing species include alternanthera, also known as joyweed (Alternanthera sp.), bougainvillea (Bougainvillea sp.), cockscomb (Celosia sp.), carnation (Dianthus sp.), globe amaranth (Gomphrena globosa), bloodleaf (Iresine sp.), and moss-rose (Portulaca grandiflora) (Polturak and Aharoni, 2018). It will be of interest to investigate the particular pigments that contribute to the coloration of these species and how those pigments can be manipulated to increase consumer appeal.

There are several betacyanin pigments that can be divided into the betanin, amaranthin, gomphrenin, and bougainvillein subgroups (Polturak and Aharoni, 2018). These subgroups were developed and named in reference to the genera from which they were first isolated. Plants in the Amaranthaceae, such as alternanthera, produce betacyanins in the amaranthin pigment group (Polturak and Aharoni, 2018). Alternanthera typically are grown as an annual bedding plant and are valued for their deep red foliar coloration and occasional variegation. Past surveys indicate that consumers have a preference for plants with red and variegated foliage (Behe et al., 1999; Berghage and Wolnick, 2000); consequently, there is potential for manipulating $\mathrm{P}$ fertility to enhance foliage coloration.

Fertilizer strategies for alternanthera recommend using a constantly supplied, complete source low in P (PanAmerican Seed Co., 2017). Specific recommendations suggest using $15 \mathrm{~N}-2.2 \mathrm{P}-12.5 \mathrm{~K}$ fertilizer mixed at a concentration of 175 to $225 \mathrm{mg} \cdot \mathrm{L}^{-1} \mathrm{~N}$. This fertilization program would provide 25.7 to $33.0 \mathrm{mg} \cdot \mathrm{L}^{-1} \mathrm{P}$, which far exceeds the optimal concentrations of 5 to $15 \mathrm{mg} \cdot \mathrm{L}^{-1} \mathrm{P}$ determined in previous studies (Henry et al., 2017, 2018). Excessive $P$ fertilization causes significant internode elongation in plants (Baas et al., 1995; Hansen and Nielsen, 2001; Henry et al., 2017, 2018; Justice and Faust, 2015), and P runoff can have negative effects on the environment (Boesch et al., 2001; Majsztrik and Lea-Cox, 2013). Furthermore, excess soil P limits mycorrhizal colonization of roots (Mosse, 1973) and has an antagonistic effect on iron and manganese uptake, leading to nutrient deficiency symptoms (Mengel et al., 2001). With recent interest in reducing $P$ fertilizer concentrations, $\mathrm{P}$ deficiency symptoms are likely to occur more frequently in commercial greenhouse plant production (Henry et al., 2018; Justice and Faust, 2015). Therefore, greater research emphasis should be placed on investigating the physiological processes affected by $\mathrm{P}$ mineral nutrition (Hernández and Munné-Bosch, 2015).

The purpose of this study was to investigate the effects of $P$ fertilization on the growth, pigmentation, and subsequent coloration of alternanthera. The first hypothesis was restricting $\mathrm{P}$ fertilization will increase foliar betacyanin concentrations similar to what is observed in anthocyanin-producing species. The second hypothesis was detrimental $\mathrm{P}$ deficiency symptoms such as excessive stunting may be overcome by providing adequate $\mathrm{P}$ during early growth, and then restricting $\mathrm{P}$ after attaining sufficient plant size. These hypotheses were tested in experiments conducted using three alternanthera cultivars.

\section{Materials and Methods}

Plant materials. Three alternanthera cultivars (Purple Prince, Brazilian Red Hots, and Little Ruby) were propagated from unrooted vegetative terminal stem cuttings. Cultivars were selected as they represent the most popular commercially available alternanthera cultivars with red foliar pigmentation. Plants were propagated in 72-cell round cell plug trays $(5.9 \mathrm{~cm}$ depth $\times 3.7 \mathrm{~cm}$ diameter; $41-\mathrm{mL}$ individual cell volume) filled with a custom substrate that was developed to limit nutrient contamination that may be present in commercial substrate 
mixes. The substrate was an 80:20 (v:v) mix of Canadian sphagnum peatmoss (Conrad Fafard, Agawam, MA) and horticultural coarse perlite (Perlite Vermiculite Packaging Industries, North Bloomfield, $\mathrm{OH}$ ), amended with mesh size \#100 dolomitic limestone (Rockydale Agricultural, Roanoke, VA) at $8.9 \mathrm{~kg} \cdot \mathrm{m}^{-3}$ and wetting agent (AquaGro $2000 \mathrm{G}$; Aquatrols, Cherry Hill, NJ) at $600 \mathrm{~g} \cdot \mathrm{m}^{-3}$. Cuttings of 'Purple Prince' were propagated on 12 Aug. 2016, whereas 'Brazilian Red Hots' and 'Little Ruby' cuttings were propagated on 5 Apr. 2017. Propagation was conducted in a glass-glazed greenhouse at North Carolina State University in Raleigh (lat. $35^{\circ} 47^{\prime} 41^{\prime} \mathrm{N}$, long. $\left.78^{\circ} 41^{\prime} 57^{\prime} \mathrm{W}\right)$. The plug trays were placed under mist set to run for $4 \mathrm{~s}$ every $32 \mathrm{~min}$ and were removed from the mist once roots were visible. After removal from the mist, all cuttings were fertilized with a solution consisting of $75 \mathrm{mg} \cdot \mathrm{L}^{-1}$ $\mathrm{N}, 5 \mathrm{mg} \cdot \mathrm{L}^{-1} \mathrm{P}$, and $75 \mathrm{mg} \cdot \mathrm{L}^{-1}$ potassium. This level of fertilizer was chosen from previous studies indicating that $5 \mathrm{mg} \cdot \mathrm{L}^{-1} \mathrm{P}$ is the lowest that could be used without detrimental P deficiency symptoms (Henry et al., 2017, 2018).

Rooted 'Purple Prince' cuttings were transplanted on 31 Aug. 2016 into 12.7-cm-diameter $(855 \mathrm{~mL})$ pots (Dillen, Middlefield, $\mathrm{OH}$ ) using the custom substrate previously described and placed on a bench in a glass-glazed greenhouse. The plants were grown under natural photoperiod with day/ night greenhouse temperature setpoints at $23.9 / 18.3^{\circ} \mathrm{C}$. Rooted 'Brazilian Red Hots' and 'Little Ruby' cuttings were transplanted on 1 May 2017 into 12.7-cm-diameter pots (Dillen) and placed on two benches in a double-layer polyethylene-glazed greenhouse covered with $35 \%$ shadecloth. Plants were grown under natural photoperiod with day/night temperature setpoints at $23.9 / 18.3{ }^{\circ} \mathrm{C}$.

Fertilization treatments. All fertilizers were custom blends of the following individual technical grade salts (Fisher Scientific, Pittsburgh, PA): calcium nitrate tetrahydrate $\left[\mathrm{Ca}\left(\mathrm{NO}_{3}\right)_{2} \cdot 4 \mathrm{H}_{2} \mathrm{O}\right]$, potassium nitrate $\left(\mathrm{KNO}_{3}\right)$, monopotassium phosphate $\left(\mathrm{KH}_{2} \mathrm{PO}_{4}\right)$, potassium sulfate $\left(\mathrm{K}_{2} \mathrm{SO}_{4}\right)$, magnesium sulfate heptahydrate $\left(\mathrm{MgSO}_{4} \cdot 7 \mathrm{H}_{2} \mathrm{O}\right)$, magnesium nitrate $\left[\mathrm{Mg}\left(\mathrm{NO}_{3}\right)_{2}\right]$, iron chelate (Fe-DTPA), manganese chloride tetrahydrate $\left(\mathrm{MnCl}_{2} \cdot 4 \mathrm{H}_{2} \mathrm{O}\right)$, zinc chloride heptahydrate $\left(\mathrm{ZnCl}_{2} \cdot 7 \mathrm{H}_{2} \mathrm{O}\right)$, copper chloride dihydrate $\left(\mathrm{CuCl}_{2} \cdot 2 \mathrm{H}_{2} \mathrm{O}\right)$, boric acid $\left(\mathrm{H}_{3} \mathrm{BO}_{3}\right)$, and sodium molybdate dihydrate $\left(\mathrm{Na}_{2} \mathrm{MoO}_{4} \cdot 2 \mathrm{H}_{2} \mathrm{O}\right)$ (Henry et al., 2018).

Fertilization treatments began the day of transplant for each cultivar. Five fertilizer concentrations of $0,2.5,5,10$, and $20 \mathrm{mg} \cdot \mathrm{L}^{-1} \mathrm{P}$ were mixed using the previously described salts (Henry et al., 2017). Phosphorus concentrations were varied among treatments, whereas other essential nutrients were adjusted to remain as constant as possible. Nitrate-nitrogen and potassium were held at $150 \mathrm{mg} \cdot \mathrm{L}^{-1}$, with all other essential microelements remaining constant (Henry et al., 2017). Fertilizer solutions were mixed in 100-L barrels and applied through drip irrigation as needed at every irrigation with an estimated $10 \%$ leaching fraction. Solution was delivered via sump pumps (model 1A; Little Giant Pump Co., Oklahoma City, OK) connected to $1.9-\mathrm{cm}$-diameter irrigation tubing fitted with drip rings (Dramm USA, Manitowoc, WI). The solution and substrate $\mathrm{pH}$ were monitored to ensure values were not excessively high due to the high fertilizer $\mathrm{NO}_{3}{ }^{-} \mathrm{N}$ content.

Each cultivar was arranged on its own greenhouse bench immediately after transplant using a completely randomized design. At the start of the experiment, there were 16 single-plant replicates grown for each of the five fertilizer concentrations $(0$,
$2.5,5,10$, and $20 \mathrm{mg} \cdot \mathrm{L}^{-1} \mathrm{P}$ ). Four weeks after transplant, onehalf of the plants grown with each of the initial four non-zero fertilizer concentrations (i.e., 2.5, 5, 10, and $20 \mathrm{mg} \cdot \mathrm{L}^{-1} \mathrm{P}$ ) were restricted to $0 \mathrm{mg} \cdot \mathrm{L}^{-1} \mathrm{P}$, whereas the other half remained on their initial concentrations. This resulted in nine total fertilization treatments, each with eight single-plant replicates. For simplicity, these nine treatments will be referred to as $0,2.5,5$, 10 , and $20 \mathrm{mg} \cdot \mathrm{L}^{-1} \mathrm{P}$ for the continuous fertility treatments, and $\Delta 2.5, \Delta 5, \Delta 10$, and $\Delta 20 \mathrm{mg} \cdot \mathrm{L}^{-1} \mathrm{P}$ to signify the treatments that were later restricted to $0 \mathrm{mg} \cdot \mathrm{L}^{-1} \mathrm{P}$.

Growth, COLOR MEASUREMENT, TISSUE SAMPLing. Biweekly measurements were collected throughout the experiment. Plant height (centimeters) was determined by measuring the highest point of the foliage from the surface of the substrate and plant diameter (centimeters) by measuring the widest point and its perpendicular axis, then averaging the two measurements. Relative chlorophyll content (RCC) was determined from the most recently matured leaves using a chlorophyll meter (SPAD-502; Konica Minolta Sensing, Osaka, Japan). Two of the most recently matured leaves were analyzed from each plant and averaged at each measurement. The measurements were taken on the leaf blade $1 \mathrm{~cm}$ from the leaf margin.

For 'Purple Prince' only, the number of branches was counted for each plant and categorized as primary branches (branches that emerge directly from the main shoot), secondary branches (branches that emerge from the primary branches), and tertiary branches (branches that emerge from the secondary branches) when applicable. The final substrate $\mathrm{pH}$ and electrical conductivity (EC) were obtained using a portable $\mathrm{pH}$ meter (HI 9813-6; Hanna Instruments, Woonsocket, RI) by means of the Pour-Thru method (Cavins et al., 2005). Whole plant vegetative tissues were severed at the substrate surface and dried for $72 \mathrm{~h}$ at $70{ }^{\circ} \mathrm{C}$ to determine final plant dry mass.

A final destructive harvest occurred after 8 weeks for each cultivar. Height, diameter, branching, and RCC were measured as previously described. Colorimetric $\left(\mathrm{L}^{*} \mathrm{a} * \mathrm{~b} *\right)$ readings were collected from the most recently matured foliage of each plant using a colorimeter (PCM/PSM; ColorTec, Clinton, NJ) with an $8-\mathrm{mm}$ aperture. Lightness $\left(\mathrm{L}^{*}\right)$ is the range from 0 (dark) to 100 (light), $\mathrm{a}^{*}$ is the range from green (negative 100) to red (positive $100)$, and $b^{*}$ is the range from blue (negative 100) to yellow (positive 100). Colorimetric values were used to calculate chroma and hue angle using equations published by McGuire (1992). As with RCC, colorimetric readings were taken on the leaf blade $1 \mathrm{~cm}$ from the leaf margin. Leaves used for color readings were then removed from each of the single-plant replicates, weighed, shredded with a sterile razor, placed into vials on ice, then frozen at $-80{ }^{\circ} \mathrm{C}$. Leaves were harvested by single-plant replicate to ensure uniform environmental exposure before freezing. Extra tissue samples also were collected to use for preliminary testing to determine a pigment extraction protocol.

Betacyanin analysis. For each single-plant replicate, $\approx 0.1$ g of frozen tissue was placed in a $50-\mathrm{mL}$ polypropylene centrifuge tube and homogenized in a $0.05 \mathrm{~m}$ phosphate buffer solution (von Elbe, 2001) using a vortex mixer. The solution volume required was determined by testing various tissue to solution ratios with extra tissue samples. Lower fertilizer $\mathrm{P}$ concentrations required more solution than greater $\mathrm{P}$ concentrations for maximum pigment extraction. Solution volumes between 5 and $30 \mathrm{~mL}$ were used. Most (98\%) of the pigment was obtained during the first extraction. Solution was then 
centrifuged at $2772 g_{\mathrm{n}}$ for $5 \mathrm{~min}$ using a swinging bucket rotor (Thermo Sorvall Legend RT; Thermo Fisher Scientific, Waltham, MA). Supernatant absorbance at 536 and $650 \mathrm{~nm}$ was determined using a spectrophotometer (UV2450; Shimadzu, Columbia, MD). The 650-nm absorbance, which represents cloudiness, was subtracted from the 536-nm absorbance, which represents the maximum absorbance for betacyanin (von Elbe, 2001). Betacyanin was determined based on the methods of Cai et al. (1998), Eq. [1]:

$$
\mathrm{AC}_{\mathrm{a}}=\left(A_{536}-A_{650}\right)(M W) V_{\mathrm{a}}(D F) \times 10^{2} / \varepsilon L W_{\mathrm{a}}
$$

where $\mathrm{AC}_{\mathrm{a}}$ is the pigment content for crude aqueous extracts, $A_{536}$ is the absorbance at $536 \mathrm{~nm}, A_{650}$ is the absorbance at 650 $\mathrm{nm}, M W$ is the molecular mass of amaranthine $(726.6 \mathrm{~g}), V_{\mathrm{a}}$ is the total extract volume (milliliters), $D F$ is the dilution factor $\left[\left(V_{\mathrm{a}}+W_{\mathrm{a}}\right) / W_{\mathrm{a}}\right]$, which normalizes for the varying tissue mass and solution volume, $\varepsilon$ is the molar absorptivity for amaranthine $\left(5.66 \times 10^{4} \mathrm{~cm}^{-1} \cdot \mathrm{mol}^{-1} \mathrm{~L}\right), L$ is the path length $(1 \mathrm{~cm})$, and $W_{\mathrm{a}}$ is the fresh weight of the tissue sample (Cai et al., 1998).

Statistical analysis. Statistical analysis was conducted using SAS (version 9.4; SAS Institute, Cary, NC). Data for plant height, diameter, dry mass, branch number, substrate $\mathrm{pH}$, and $\mathrm{EC}, \mathrm{RCC}, \mathrm{L}^{*} \mathrm{a} \mathrm{b}^{*}$, chroma, and hue angle were subjected to analysis of variance using PROC ANOVA in SAS to determine significant interactions for further analysis. Leastsquared means were separated with PROC GLIMMIX using the Tukey adjustment at $P \leq 0.05$. Correlation among betacyanin concentration, hue angle, and RCC values was determined with PROC CORR. Correlations were calculated separately for continuous and restricted $\mathrm{P}$ treatments due to diverging patterns in color and pigment concentrations. Regression was conducted using PROC REG and PROC NLIN depending on the selected model. Models used in this study include linear, quadratic, cubic, and plateaus. The Akaike information criterion was used for best-fit model selection based on the lowest Akaike information criterion value. The adjusted coefficient of determination $\left(r^{2}\right)$ also was calculated and is reported with each model for reference.

\section{Results and Discussion}

Plants grown with $20 \mathrm{mg} \cdot \mathrm{L}^{-1} \mathrm{P}$ were considered control plants, representing the commercial fertilizers mixed using recommended concentrations used by commercial producers. These plants exhibited the growth and color characteristics that would be observed in a typical commercial production greenhouse. Visual differences for 'Purple Prince', 'Brazilian Red Hots', and 'Little Ruby' may be observed in Fig. 1A, B, and C, respectively.

Plant Growth. Within cultivars, the height of 'Purple Prince' and 'Brazilian Red Hots' was significantly affected by the different $\mathrm{P}$ concentrations but was not different between continuous and restricted $\mathrm{P}$ treatments. Therefore, values were combined for each concentration and height analyses were conducted without regard to fertilization treatment. Quadratic plateau models provided the best-fit for height data. Plants grown without $\mathrm{P}$ were stunted, attaining the lowest heights. Regression analysis indicated that 'Purple Prince' height was maximized $(32.8 \mathrm{~cm})$ with $8.0 \mathrm{mg} \cdot \mathrm{L}^{-1} \mathrm{P}$ (Fig. 2A). Regression analysis of 'Brazilian Red Hots' indicated height was

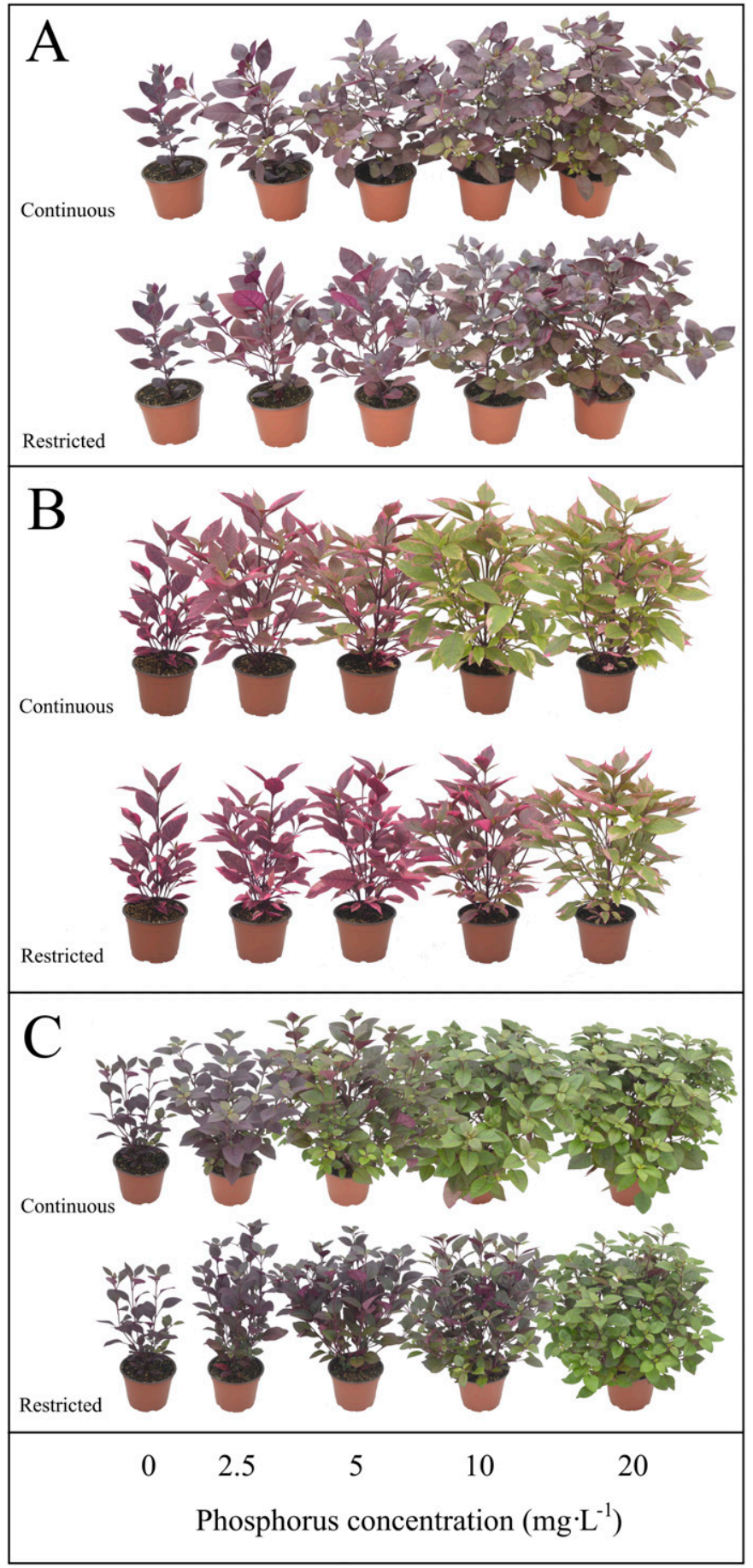

Fig. 1. Images of (A) 'Purple Prince', (B) 'Brazilian Red Hots', and (C) 'Little Ruby' alternanthera plants grown with $0,2.5,5,10$, or $20 \mathrm{mg} \cdot \mathrm{L}^{-1}$ phosphorus (P) for 8 weeks or grown with $2.5,5,10$, or $20 \mathrm{mg} \cdot \mathrm{L}^{-1} \mathrm{P}$ for 4 weeks, and then restricted to $0 \mathrm{mg} \cdot \mathrm{L}^{-1} \mathrm{P}$ for an additional 4 weeks. Within each image, the top row illustrates plants that received the same $\mathrm{P}$ concentration for the entire study, and the bottom row illustrates plants with $\mathrm{P}$ restricted to $0 \mathrm{mg} \cdot \mathrm{L}^{-1} 4$ weeks after transplant.

maximized $\left(35.7 \mathrm{~cm}\right.$ ) with $3.1 \mathrm{mg} \cdot \mathrm{L}^{-1} \mathrm{P}$ (Fig. $\left.2 \mathrm{~B}\right)$. In contrast, $\mathrm{P}$ concentrations used in this study did not have a significant effect on the height of 'Little Ruby' plants (average maximum of $34.4 \mathrm{~cm}$ ), which developed a wider spreading habit compared with the other cultivars. 

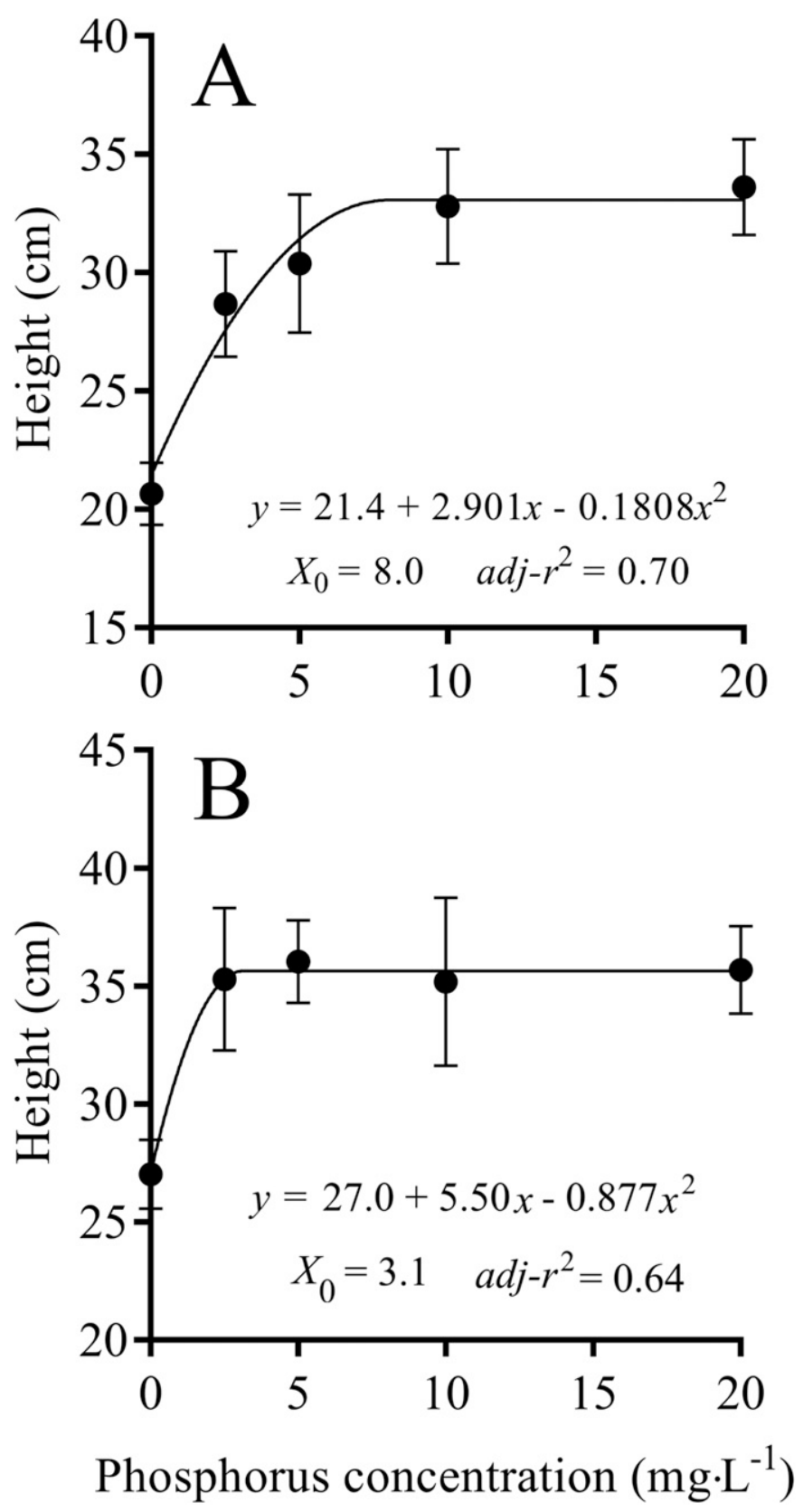

Fig. 2. Quadratic plateau regression models for height of (A) 'Purple Prince' and (B) 'Brazilian Red Hots' alternanthera plants grown with 0, 2.5, 5, 10, or 20 $\mathrm{mg} \cdot \mathrm{L}^{-1}$ phosphorus $(\mathrm{P})$ for 8 weeks or grown with $2.5,5,10$, or $20 \mathrm{mg} \cdot \mathrm{L}^{-1} \mathrm{P}$ for 4 weeks, and then restricted to $0 \mathrm{mg} \cdot \mathrm{L}^{-1} \mathrm{P}$ for an additional 4 weeks. $X_{0}$ represents the $\mathrm{P}$ concentration at which the model plateaus and further increases in growth are not observed.

Phosphorus concentrations significantly affected plant diameter in each cultivar. The diameter of each cultivar was significantly increased by $\mathrm{P}$ concentration, but only 'Purple Prince' exhibited a significant difference between the continuous and restricted fertility treatments. The quadratic plateau model demonstrated the best fit for 'Purple Prince' plants grown with continuous $\mathrm{P}$ fertilization. Regression analysis demonstrated diameter was maximized at $48 \mathrm{~cm}$ with a $\mathrm{P}$ concentration of $8.4 \mathrm{mg} \cdot \mathrm{L}^{-1} \mathrm{P}$ (Fig. 3A). In contrast, the restricted $\mathrm{P}$ fertility treatment exhibited a quadratic response, and the greatest difference between the two models was
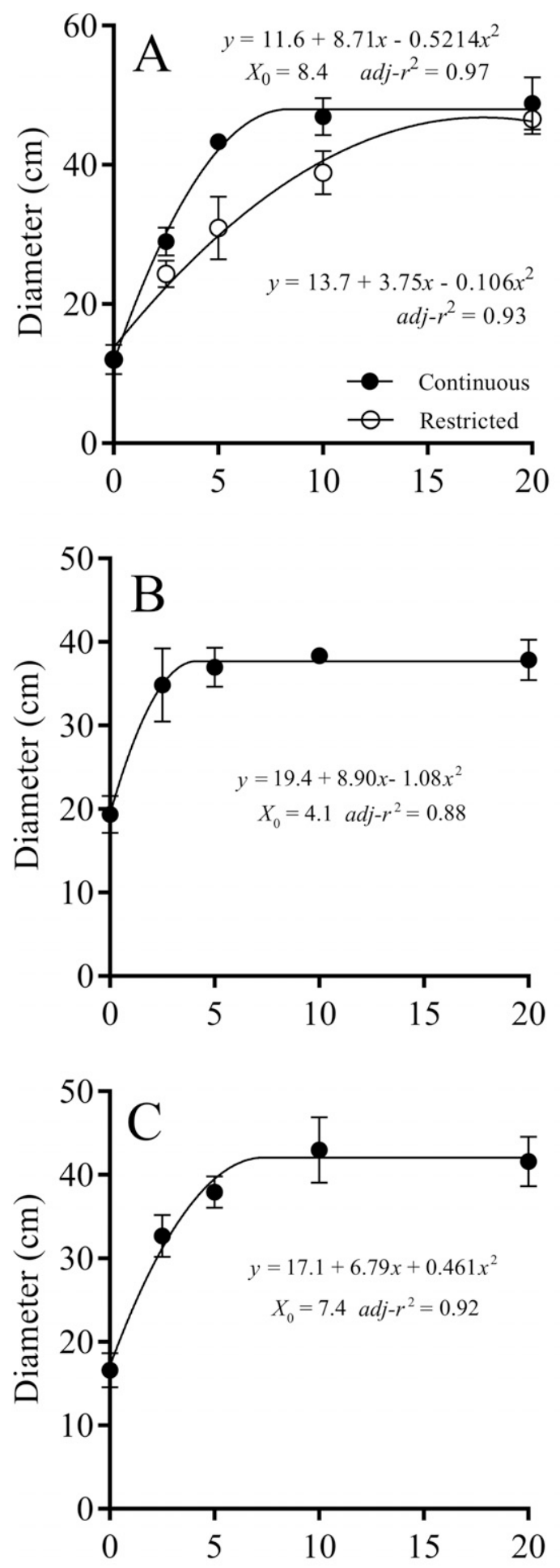

Phosphorus concentration $\left(\mathrm{mg} \cdot \mathrm{L}^{-1}\right)$

Fig. 3. Regression models illustrating diameter of (A) 'Purple Prince', (B) 'Brazilian Red Hots', and (C) 'Little Ruby' alternanthera plants grown with 0, $2.5,5,10$, or $20 \mathrm{mg} \cdot \mathrm{L}^{-1}$ phosphorus $(\mathrm{P})$ for 8 weeks or grown with $2.5,5,10$, or $20 \mathrm{mg} \cdot \mathrm{L}^{-1} \mathrm{P}$ for 4 weeks, and then restricted to $0 \mathrm{mg} \cdot \mathrm{L}^{-1} \mathrm{P}$ for an additional 4 weeks. Data were similar between continuous and restricted treatments, so data were combined for 'Brazilian Red Hots' and 'Little Ruby'. $X_{0}$ represents the $\mathrm{P}$ concentration at which the model plateaus and further increases in growth are not observed. 
observed between 5 and $10 \mathrm{mg} \cdot \mathrm{L}^{-1} \mathrm{P}$ (Fig. 3A). This indicates that $\Delta 5$ and $\Delta 10 \mathrm{mg} \cdot \mathrm{L}^{-1} \mathrm{P}$ can provide moderate growth control of plant diameter. The quadratic plateau model also demonstrated the best fit for 'Brazilian Red Hots' and 'Little Ruby' diameter, which, based on regression, reached average maxima with 4.1 and $7.4 \mathrm{mg} \cdot \mathrm{L}^{-1} \mathrm{P}$, respectively (Fig. 3B and C).

The observed differences in height and diameter indicate that $\Delta 5$ and $\Delta 10 \mathrm{mg} \cdot \mathrm{L}^{-1} \mathrm{P}$ may be used as part of a growth control management strategy for alternanthera. These results are in agreement with those reported by Henry et al. (2017, 2018). Previous studies demonstrate low $P$ fertility effects on the growth and development of various plant species (Baas et al., 1995; Hansen and Nielsen, 2001; Henry et al., 2017, 2018; Justice and Faust, 2015). These studies indicate plants grown in soilless substrates typically require at least $5 \mathrm{mg} \cdot \mathrm{L}^{-1} \mathrm{P}$ to prevent $\mathrm{P}$ deficiency symptom development. In contrast, plants grown in soil-based substrates, or substrates amended with nutrient-buffered clay, may require $1 \mathrm{mg} \cdot \mathrm{L}^{-1} \mathrm{P}$ or less to prevent deficiency symptoms (Hansen and Nielsen, 2001). The discrepancy observed here is likely due to the low P-holding capacity of peatmoss and other common components of soilless substrates (Marconi and Nelson, 1984).

Branching also was affected by $P$ concentration. The number of branches emerging from the main stem of 'Purple Prince' ranged from 10 to 32 . The number of secondary branches emerging from primary branches also increased with $\mathrm{P}$ concentration, although the range was much greater. There were no secondary branches observed on plants grown without $\mathrm{P}$ and up to 135 secondary branches on plants grown with $20 \mathrm{mg} \cdot \mathrm{L}^{-1} \mathrm{P}$. Plants grown with either 10,20 , or $\Delta 20 \mathrm{mg} \cdot \mathrm{L}^{-1} \mathrm{P}$ had the greatest total number of branches, whereas plants grown without $\mathrm{P}$ had fewest (Fig. 4).

The $\mathrm{pH}$ of 'Purple Prince' plants varied little across $\mathrm{P}$ fertilizer regimes, which ranged from 6.5 to 6.6. Substrate EC increased with initial $\mathrm{P}$ concentration for plants grown with the

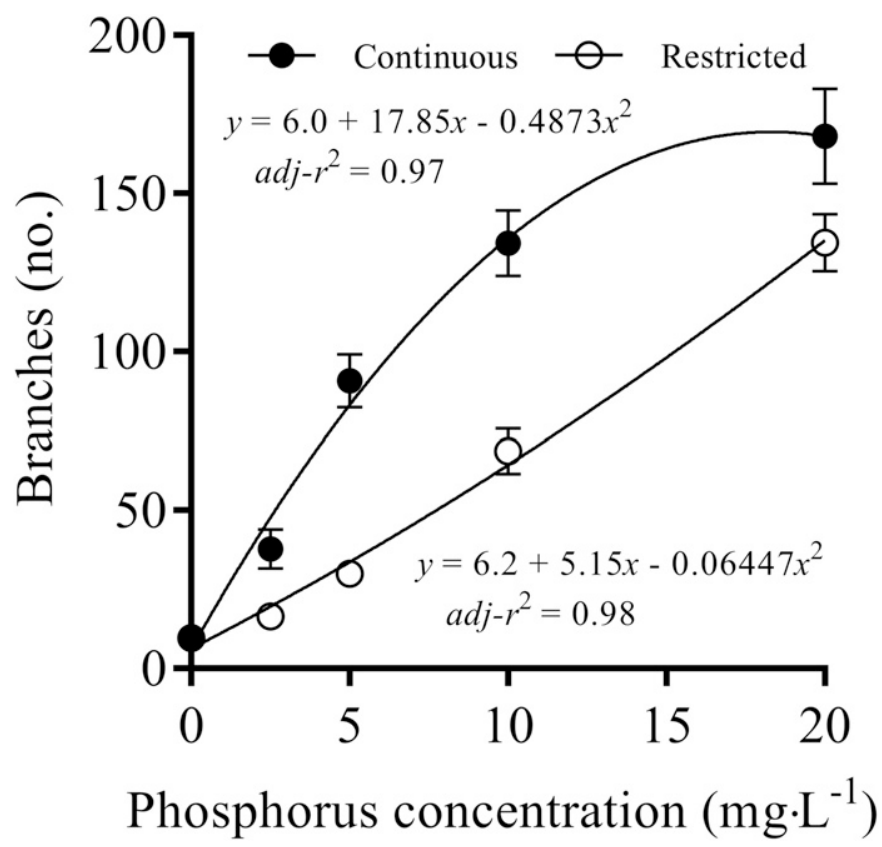

Fig. 4. Regression model illustrating the total number of axillary branches to develop on 'Purple Prince' alternanthera in response to 8 weeks of continuous fertilization using $0,2.5,5,10$, or $20 \mathrm{mg} \cdot \mathrm{L}^{-1}$ phosphorus. restricted $\mathrm{P}$ treatment (Fig. 5). This trend demonstrates that restricted $P$ fertility inhibited nutrient uptake, leading to increased soluble salts in the substrate. In addition, visual inspection of the root systems demonstrated substantial root growth limitation. Therefore, care must be taken to adjust fertilization frequency and nutrient concentrations to balance for the reduction in $\mathrm{P}$ and subsequent reduction in growth rate.

LEAF COLOR AND RCC. RCC exhibited an increasing trend in the most recently matured foliage of plants grown with continuous $\mathrm{P}$ fertility, up to a concentration of $5 \mathrm{mg} \cdot \mathrm{L}^{-1} \mathrm{P}$ (Fig. 6). After this point, RCC exhibited a slight decrease with increasing $\mathrm{P}$ concentration. RCC was significantly lower in plants grown with the $\Delta 2.5, \Delta 5$, and $\Delta 10 \mathrm{mg} \cdot \mathrm{L}^{-1} \mathrm{P}$ treatments compared with plants grown with the $2.5,5$, and $10 \mathrm{mg} \cdot \mathrm{L}^{-1} \mathrm{P}$ treatments, respectively. However, the restricted $\mathrm{P}$ regression model demonstrated an increasing trend from the $\Delta 5$ to the $\Delta 20$ $\mathrm{mg} \cdot \mathrm{L}^{-1} \mathrm{P}$ treatment.

Leaf color (red-purple) was significantly affected by $\mathrm{P}$ concentration and was determined with several different measurements. In our study, hue was considered the most important parameter for measuring color, as it provided a value that could be directly compared with a corresponding color. A linear increase in hue was observed in 'Purple Prince' plants with increasing $\mathrm{P}$ concentration, moving away from the purple end of the red spectrum and toward the orange end. As the response between each continuous and restricted $\mathrm{P}$ concentration was similar, data were combined (Fig. 7A). Hue values for 'Brazilian Red Hots' followed different trends depending on whether $\mathrm{P}$ was delivered continuously or was restricted (Fig. 7B). Plants grown with $0,2.5,5, \Delta 2.5, \Delta 5$, and $\Delta 10 \mathrm{mg} \cdot \mathrm{L}^{-1} \mathrm{P}$ had hue values close to $350^{\circ}$, which is in the red spectrum nearer to violet. In contrast, plants grown with 10,20 , and $\Delta 20$ $\mathrm{mg} \cdot \mathrm{L}^{-1} \mathrm{P}$ had hue values between 0 and $5^{\circ}$, which is in the red

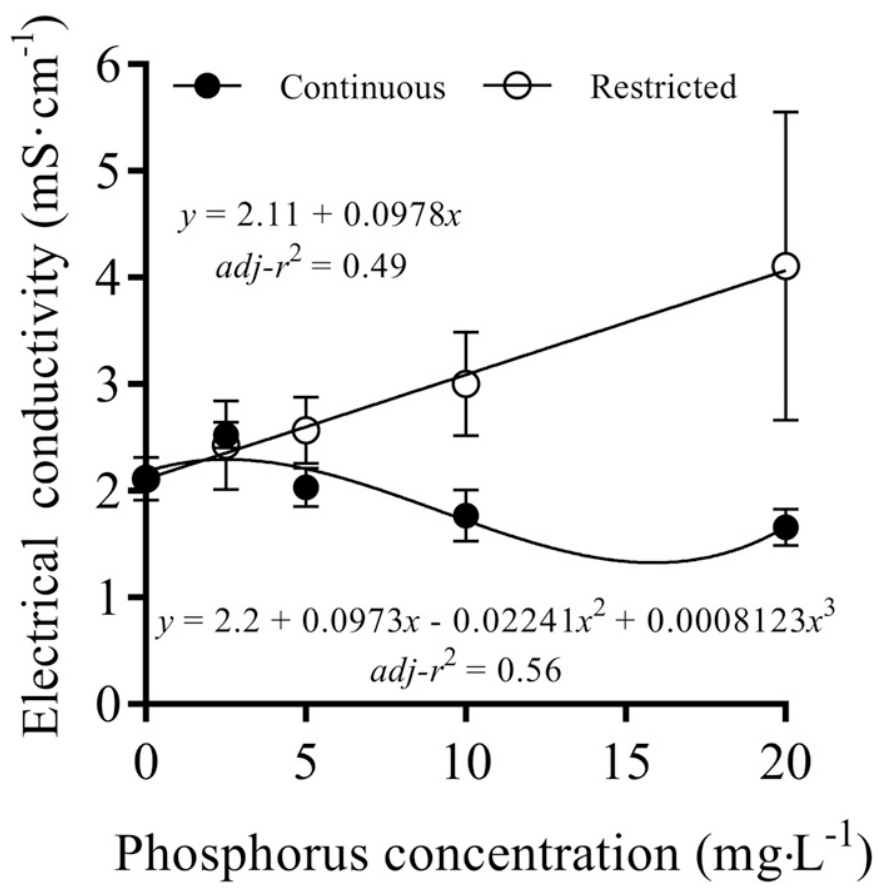

Fig. 5. Regression models demonstrating substrate electrical conductivity values for 'Purple Prince' alternanthera plants grown with $0,2.5,5,10$, or $20 \mathrm{mg} \cdot \mathrm{L}^{-1}$ phosphorus $(\mathrm{P})$ for 8 weeks or grown with $2.5,5,10$, or $20 \mathrm{mg} \cdot \mathrm{L}^{-1} \mathrm{P}$ for 4 weeks, and then restricted to $0 \mathrm{mg} \cdot \mathrm{L}^{-1} \mathrm{P}$ for an additional 4 weeks. 


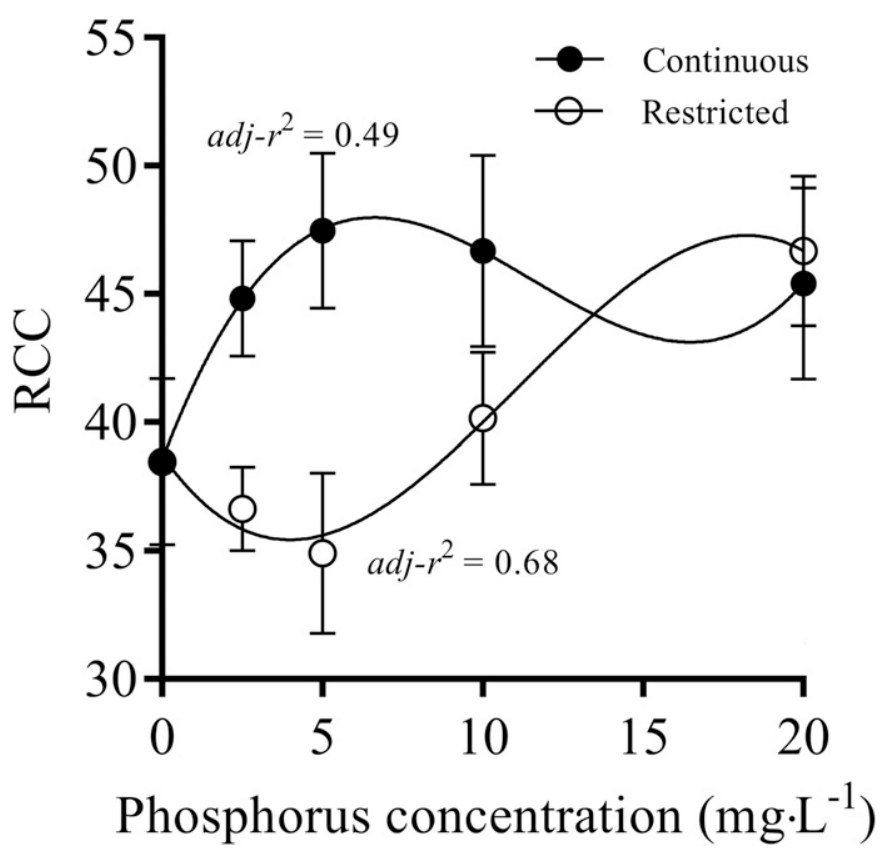

Fig. 6. Regression models demonstrating relative chlorophyll content (RCC) for 'Purple Prince' alternanthera foliage grown with $0,2.5,5,10$, or $20 \mathrm{mg} \cdot \mathrm{L}^{-1}$ phosphorus (P) for 8 weeks or grown with $2.5,5,10$, or $20 \mathrm{mg} \cdot \mathrm{L}^{-1} \mathrm{P}$ for 4 weeks, and then restricted to $0 \mathrm{mg} \cdot \mathrm{L}^{-1} \mathrm{P}$ for an additional 4 weeks.

spectrum. Similarly, 'Little Ruby' exhibited a trend where 0 , $2.5, \Delta 2.5$, and $\Delta 5 \mathrm{mg} \cdot \mathrm{L}^{-1} \mathrm{P}$ resulted in hue values on the redviolet spectrum, whereas plants grown with 10,20 , and $\Delta 20$ $\mathrm{mg} \cdot \mathrm{L}^{-1} \mathrm{P}$ had values near $20^{\circ}$, in the red spectrum (Fig. $7 \mathrm{C}$ ).

Color intensity, or chroma, also shifted inversely with $\mathrm{P}$ concentration. For instance, 'Brazilian Red Hots' exhibited decreasing chroma with increasing $\mathrm{P}$ concentration (Fig. 8A). Decreased chroma was accompanied by increased lightness, as measured in the $\mathrm{L}^{*} \mathrm{a}^{*} \mathrm{~b}^{*}$ color space (Fig. 8B). Lightness exhibited an increasing trend in 'Purple Prince' and 'Little Ruby' plants with increasing $P$ concentration (data not shown). All cultivars in this study exhibited a visually redder coloration when grown with low or restricted P concentrations. Overall, fertilizer $\mathrm{P}$ concentrations greatly influenced the growth and leaf coloration in the three alternanthera cultivars grown.

Hue angle was positively correlated with RCC for continuous (0.41) and restricted (0.38) $\mathrm{P}$ fertilizer treatments. $\mathrm{Nu}-$ merous studies report strong correlations between chlorophyll meter and colorimeter measurements for estimating RCC. Madeira et al. (2003) report a high correlation between RCC and colorimetric measurements in sweet pepper (Capsicum annuum) leaves. León et al. (2007) report similarly strong correlations between RCC, and colorimetric measurements for estimating RCC in butterhead lettuce (Lactuca sativa). However, it is important to consider that these correlations are observed on plants with green foliage, and these relationships may differ when influenced by pigments other than chlorophyll.

No published research appears to discuss estimating foliar betacyanins via chlorophyll meter, colorimeter, or similar instruments, but some work has investigated these measurements in relation to foliar anthocyanins.

A high correlation between colorimetric readings and anthocyanin content was reported for nine lettuce cultivars (Gazula et al., 2007); chlorophyll meter measurements are
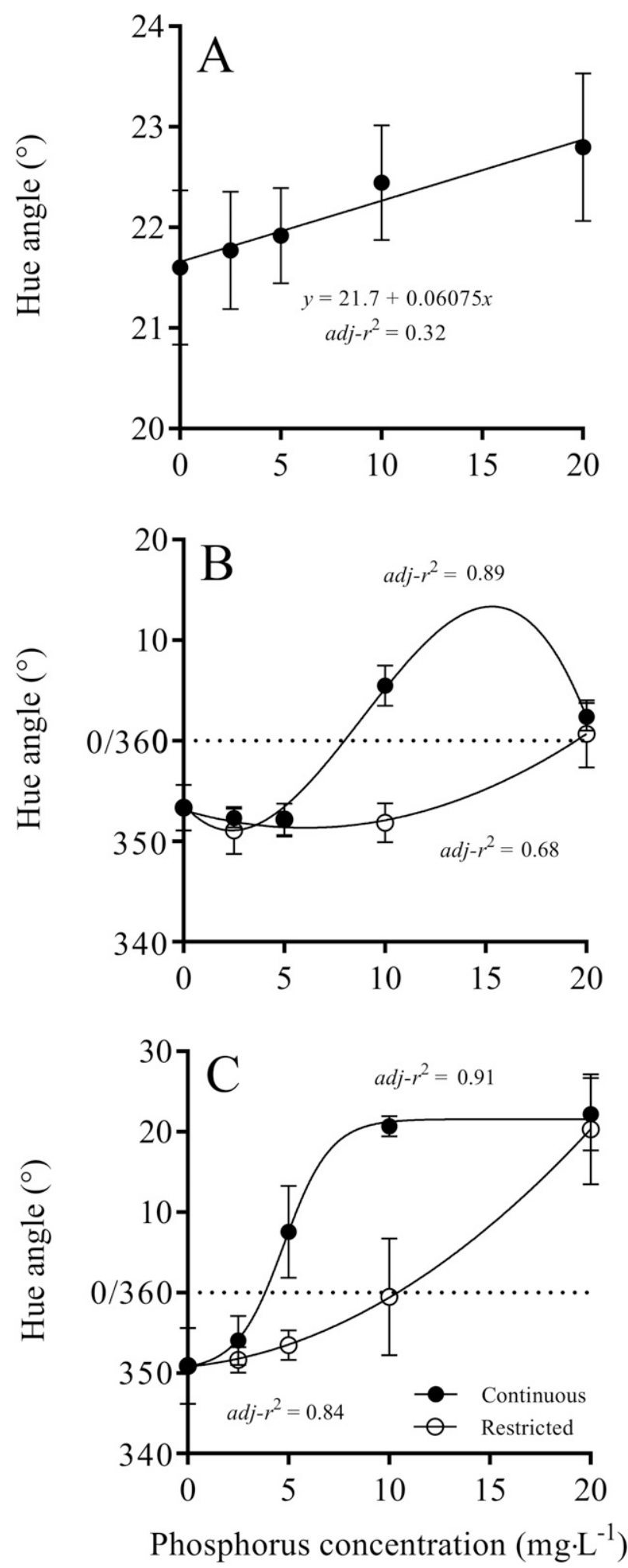

Fig. 7. Regression models demonstrating hue angle of (A) 'Purple Prince', (B) 'Brazilian Red Hots', and (C) 'Little Ruby' alternanthera foliage grown with $0,2.5,5,10$, or $20 \mathrm{mg} \cdot \mathrm{L}^{-1}$ phosphorus (P) for 8 weeks or grown with $2.5,5,10$, or $20 \mathrm{mg} \cdot \mathrm{L}^{-1} \mathrm{P}$ for 4 weeks, and then restricted to $0 \mathrm{mg} \cdot \mathrm{L}^{-1} \mathrm{P}$ for an additional 4 weeks.

inconsistent when measuring leaves with an anthocyanin to chlorophyll ratio (measured in $\mathrm{nmol} \cdot \mathrm{m}^{-2}$ ) greater than 1 (Hlavinka et al., 2013). For instance, high foliar anthocyanin 

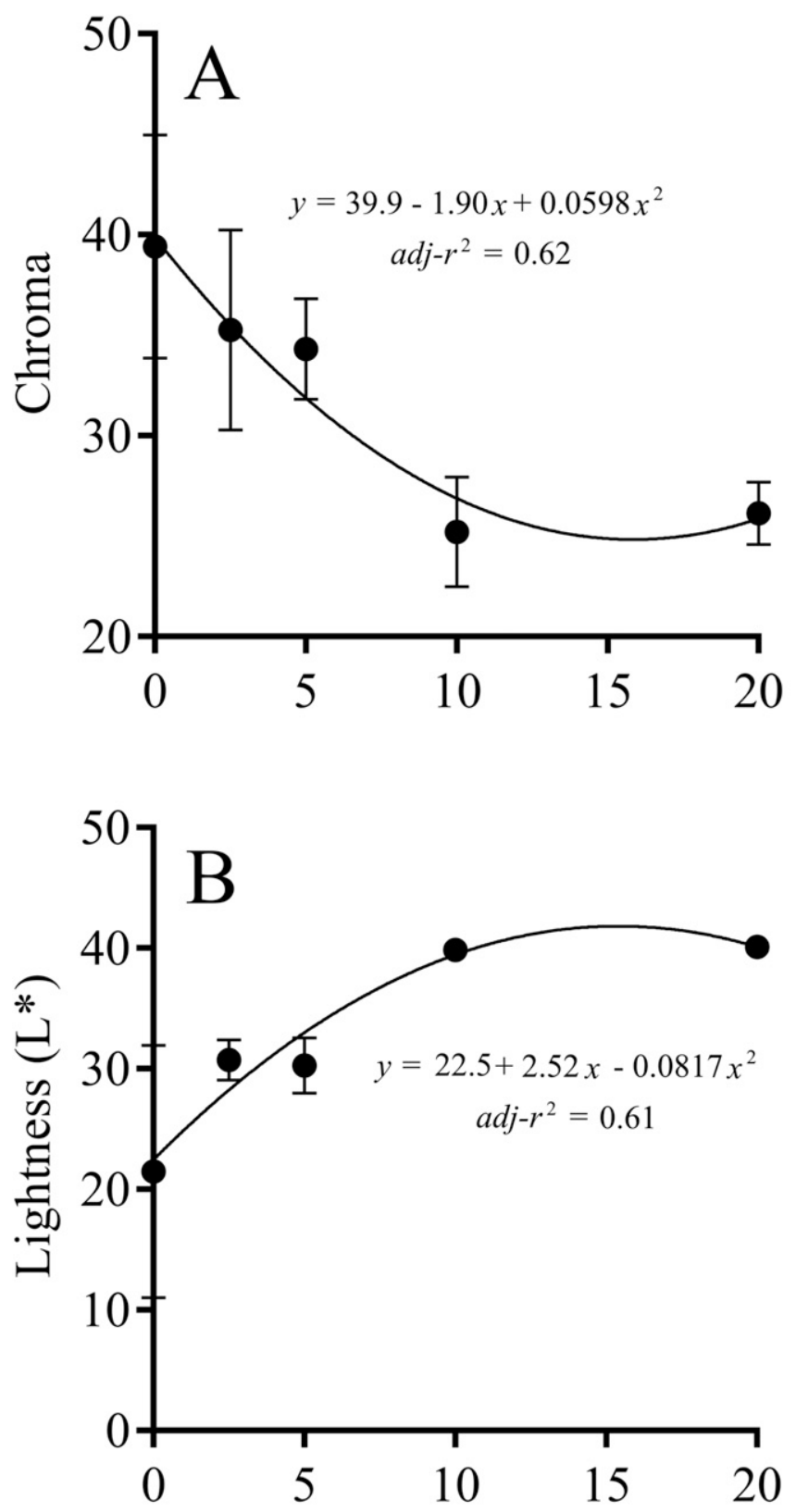

\section{Phosphorus concentration $\left(\mathrm{mg} \cdot \mathrm{L}^{-1}\right)$}

Fig. 8. Regression models demonstrating (A) chroma and (B) lightness of 'Brazilian Red Hots' alternanthera foliage grown with $0,2.5,5,10$, or 20 $\mathrm{mg} \cdot \mathrm{L}^{-1}$ phosphorus (P) for 8 weeks or grown with $2.5,5,10$, or $20 \mathrm{mg} \cdot \mathrm{L}^{-1} \mathrm{P}$ for 4 weeks, and then restricted to $0 \mathrm{mg} \cdot \mathrm{L}^{-1} \mathrm{P}$ for an additional 4 weeks.

concentrations appear to reduce RCC estimation accuracy in tomato foliage when using a chlorophyll meter (Hlavinka et al., 2013) but do not reduce estimation efficacy in rose (Rosa sp.), eucalyptus (Eucalyptus sp.), castor bean (Ricinus communis), or sugar maple (Acer saccharum) (Cate and Perkins, 2003; Manetas et al., 1998). Li et al. (2017) also demonstrate high correlations between chlorophyll meter measurements and $\mathrm{RCC}$ in the anthocyanin-rich senescing leaves of painted maple (Acer pictum ssp. mono), amur maple (Acer ginnala), mongolian oak (Quercus mongolica), and Siberian dogwood (Cornus alba). Out of these species, only mongolian oak had a significant correlation between chlorophyll meter measurements and anthocyanin content (Li et al., 2017). This indicates chlorophyll meters may be poor anthocyanin estimators and, therefore, may be similarly inaccurate for measuring foliar betacyanins due to the similarities of these two pigments.

Foliar Pigmentation. Betacyanin concentrations in 'Purple Prince' were significantly affected by $\mathrm{P}$ fertility and $\mathrm{P}$ restriction (Fig. 9). Plants grown without $\mathrm{P}$ had the greatest betacyanin concentrations, averaging $269 \mathrm{mg} / 100 \mathrm{~g}$ fresh weight. The $\Delta 2.5, \Delta 5$, and $5 \mathrm{mg} \cdot \mathrm{L}^{-1} \mathrm{P}$ treatments resulted in betacyanin concentrations that were about one-half that of the $0 \mathrm{mg} \cdot \mathrm{L}^{-1} \mathrm{P}$ treatment. The intersection of the 5 and $\Delta 5 \mathrm{mg} \cdot \mathrm{L}^{-1} \mathrm{P}$ regression models marked a sudden inverse trend in the restricted $\mathrm{P}$ plants, where betacyanin concentrations increased from an average of 170 to $226 \mathrm{mg} / 100 \mathrm{~g}$ fresh weight for the $\Delta 5$ and $\Delta 10 \mathrm{mg} \cdot \mathrm{L}^{-1} \mathrm{P}$ treatments, respectively. In contrast, betacyanin concentrations in plants grown with $10 \mathrm{mg} \cdot \mathrm{L}^{-1} \mathrm{P}$ averaged $13.5 \mathrm{mg} / 100 \mathrm{~g}$, which did not change with increasing $\mathrm{P}$ concentration. This illustrates a 16-fold difference in betacyanins based solely on whether the $\mathrm{P}$ concentration remained at $10 \mathrm{mg} \cdot \mathrm{L}^{-1}$ for the entire study was restricted 4 weeks after transplant. Plants grown with the $\Delta 20 \mathrm{mg} \cdot \mathrm{L}^{-1} \mathrm{P}$ treatment did not follow the increasing trend in betacyanin concentration observed between the $\Delta 5$ and $\Delta 10 \mathrm{mg} \cdot \mathrm{L}^{-1} \mathrm{P}$ treatments. Furthermore, the betacyanin concentrations resulting from the $\Delta 20 \mathrm{mg} \cdot \mathrm{L}^{-1} \mathrm{P}$ treatment were similar to the $20 \mathrm{mg} \cdot \mathrm{L}^{-1} \mathrm{P}$ treatment. The similarities in betacyanin concentrations were most likely due to ample $P$ reserves being contained in the $\Delta 20$ $\mathrm{mg} \cdot \mathrm{L}^{-1} \mathrm{P}$ plants that limited betacyanin accumulation. A possible explanation for the observed relationship between $\mathrm{P}$ nutrition and betacyanin content may be due to the effect of $\mathrm{P}$ on growth. One of the primary physiological effects of $\mathrm{P}$ deficiency is decreased cell division (Deroles, 2009). In this case, betacyanin biosynthesis may not be affected, but the betacyanin concentration would increase due to fewer cells.

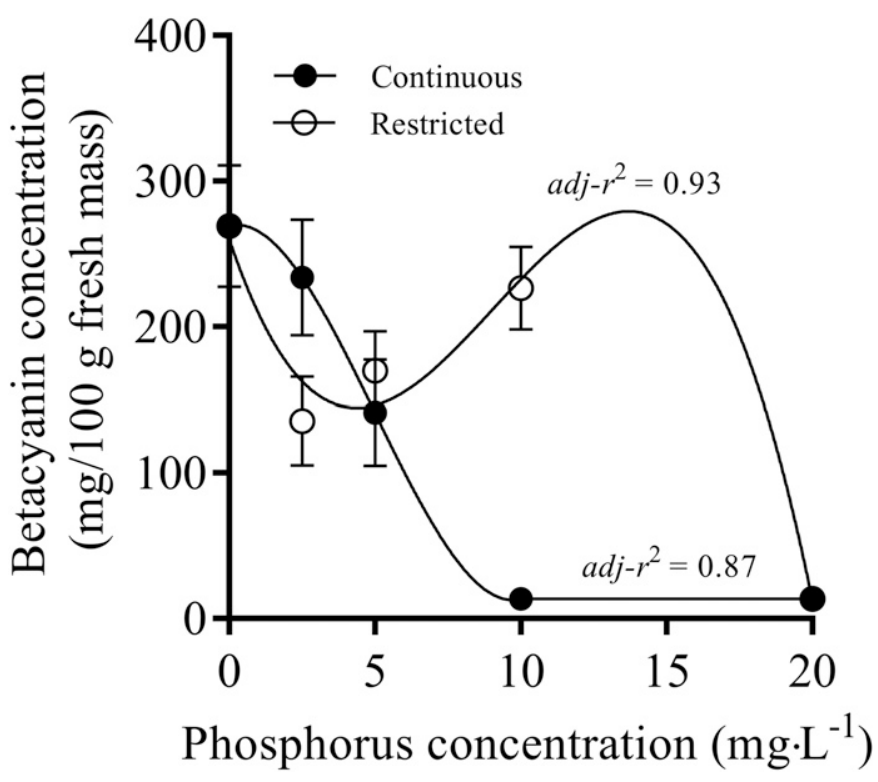

Fig. 9. Regression models demonstrating 'Purple Prince' alternanthera foliar betacyanin concentrations in plants grown with $0,2.5,5,10$, or $20 \mathrm{mg} \cdot \mathrm{L}^{-1}$ phosphorus (P) for 8 weeks or plants grown with $2.5,5,10$, or $20 \mathrm{mg} \cdot \mathrm{L}^{-1} \mathrm{P}$ for 4 weeks, and then restricted to $0 \mathrm{mg} \cdot \mathrm{L}^{-1} \mathrm{P}$ for an additional 4 weeks. 
Significant differences in betacyanin concentration have been observed previously in alternanthera when exposed to different stresses and stimuli (Silva et al., 2005). For instance, alternanthera plants had greater betacyanin accumulation when cultured on media containing tyrosine, an important betacyanin precursor. In contrast, betacyanin accumulation and cell division were inhibited when cultured on media containing 2,4-D (Silva et al., 2005). In addition, differences in betacyanin concentration have been observed based on genotype, growth stage, and plant part. For instance, betacyanin concentration in red amaranth (Amaranthus cruentus) leaves were found to decrease 10-fold over the course of 10 weeks of maturation (Cai et al., 1998). Shin et al. (2003) reported that light quality has a significant effect on betalain accumulation in beet. It was found that a combination of blue and far-red light-emitting diodes (LEDs) was best for betalain enhancement, and that red LEDs alone or in combination with far-red LEDs significantly limited betalain accumulation (Shin et al., 2003). Stagnari et al. (2014) reported a $52 \%$ increase in betacyanins in response to drought in beet. Betacyanins also have been shown to increase in response to salt stress in new zealand ice plant (Disphyma australe) exposed to high levels of sodium chloride (Jain and Gould, 2015b).

The regression models observed in the present study demonstrate that $\mathrm{P}$ mineral nutrition has a significant impact on betacyanin accumulation in alternanthera foliage (Fig. 9). Correlation between hue and betacyanin demonstrates a moderate to strong negative correlation in plants grown using the continuous ( -0.87$)$ and restricted $(-0.52) \mathrm{P}$ treatments (Fig. 10). This is similar to what was observed by Gazula et al. (2007), who report significant correlation between color measurements and foliar anthocyanins. Betacyanin concentration also was negatively correlated with RCC for continuous $(-0.47)$ and restricted $(-0.54) \mathrm{P}$ treatments. Anthocyanin research finds inconsistent correlations with chlorophyll meter measurements that vary significantly by species (Hlavinka et al., 2013; Li et al., 2017). It will be of interest to determine whether other stressors increase betacyanin concentrations in alternanthera foliage and how these stressors affect chlorophyll meter and colorimeter measurements. Furthermore, research should investigate whether $P$ fertility and other stressors have the same effects on foliar betacyanins in other plant species. Both the fertilizer P concentration and the fertilization treatment (i.e., continuous or restricted) affected betacyanin concentrations in
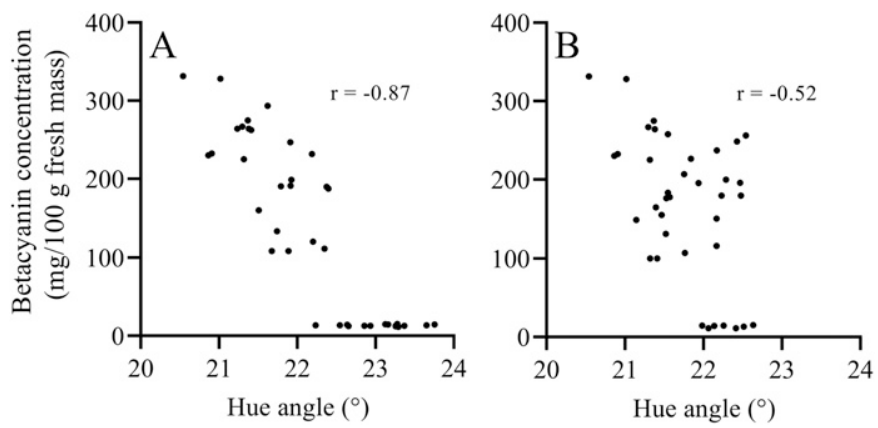

Fig. 10. Correlation between foliar betacyanin concentrations and hue angle in (A) alternanthera ('Purple Prince') plants grown with continuous phosphorus (P) fertilization using $0,2.5,5,10$, or $20 \mathrm{mg} \cdot \mathrm{L}^{-1} \mathrm{P}$ for 8 weeks or (B) alternanthera plants grown with $2.5,5,10$, or $20 \mathrm{mg} \cdot \mathrm{L}^{-1} \mathrm{P}$ for 4 weeks, and then restricted to $0 \mathrm{mg} \cdot \mathrm{L}^{-1} \mathrm{P}$ for an additional 4 weeks. unique ways. The cause of this specific response remains unknown, but further research may elucidate the function of $\mathrm{P}$ to the biosynthetic pathway of betacyanins.

\section{Conclusions}

Alternanthera grown with low but sufficient levels of $\mathrm{P}$ fertility between 5 and $10 \mathrm{mg} \cdot \mathrm{L}^{-1} \mathrm{P}$ were simultaneously more compact and had enhanced red coloration compared with plants grown with $20 \mathrm{mg} \cdot \mathrm{L}^{-1} \mathrm{P}$. Plants that were grown with $\mathrm{P}$ restricted 4 weeks after transplant were typically as red or redder compared with plants grown with the corresponding continuous $\mathrm{P}$ fertilization. Providing sufficient $\mathrm{P}$ for the first several weeks enabled plants to develop adequately before withholding $\mathrm{P}$ to induce increased betacyanin biosynthesis. From a production standpoint, this enables plants to attain sufficient size for marketing. Refinement of this fertilization strategy should be considered, as unintended P deficiency symptoms could render a crop unmarketable. Restricting $\mathrm{P}$ appears to provide sufficient $P$ as to prevent the negative aspects of $\mathrm{P}$ deficiency while still enhancing coloration. Commercial alternanthera producers can use $\mathrm{P}$ concentrations of $5 \mathrm{mg} \cdot \mathrm{L}^{-1}$ restricted to $2.5 \mathrm{mg} \cdot \mathrm{L}^{-1} \mathrm{P}$ in the latter half of production to enhance coloration and keep plants compact. However, it is critical to note that these results are only applicable for plant production in soilless substrates and are not applicable to plants grown in the landscape or other soil-based substrates with high P holding capacity. This study also provides the first evidence that betacyanin concentration can be influenced by P fertilization and further investigation is needed to understand the specific role of $\mathrm{P}$ in betacyanin synthesis and accumulation.

\section{Literature Cited}

Baas, R., A. Brandts, and N. Straver. 1995. Growth regulation of bedding plants and poinsettia using low phosphorous fertilization and ebb and flow irrigation. Acta Hort. 378:129-137.

Behe, B., R. Nelson, S. Barton, C. Hall, C.D. Safley, and S. Turner. 1999. Consumer preferences for geranium flower color, leaf variegation, and price. HortScience 34:740-742.

Berghage, R. and D. Wolnick. 2000. Consumer color preference in new guinea impatiens. HortTechnology 10:206-208.

Boesch, D.F., R.B. Brinsfield, and R.E. Magnien. 2001. Chesapeake Bay eutrophication. J. Environ. Qual. 30:303-320.

Boldt, J.K. 2013. Foliar anthocyanins in coleus and ornamental grasses, accumulation, localization, and function. Univ. Minnesota, Minneapolis, PhD Diss.

Brockington, S.F., R.H. Walker, B.J. Glover, P.S. Soltis, and D.E. Soltis. 2011. Complex pigment evolution in the Caryophyllales. New Phytol. 190:854-864.

Cai, Y., M. Sun, H. Wu, R. Huang, and H. Corke. 1998. Characterization and quantification of betacyanin pigments from diverse Amaranthus species. J. Agr. Food Chem. 46:2063-2070.

Cate, T.M. and T. Perkins. 2003. Chlorophyll content monitoring in sugar maple (Acer saccharum). Tree Physiol. 23:1077-1079.

Cavins, T.J., B.E. Whipker, and W. Fonteno. 2005. Timing of PourThru affects $\mathrm{pH}$, electrical conductivity, and leachate volume. Commun. Plant Soil Sci. 36:1573-1581.

Chen, R., S. Song, X. Li, H. Liu, and D. Huang. 2013. Phosphorus deficiency restricts plant growth but induces pigment formation in the flower stalk of chinese kale. Hort. Environ. Biotechnol. 54:243248.

Clement, J. and T. Mabry. 1996. Pigment evolution in the Caryophyllales: A systematic overview. Bot. Acta 109:360-367.

Cobbina, J. and M. Miller. 1987. Purpling in maize hybrids as influenced by temperature and soil phosphorus. Agron. J. 79:576-582. 
Deroles, S. 2009. Anthocyanin biosynthesis in plant cell cultures: A potential source of natural colourants, p. 107-167. In: K. Gould, K.M. Davies, and C. Winefield (eds.). Anthocyanins: Biosynthesis, functions, and applications. Springer, New York, NY.

Ehrendorfer, F. 1976. Closing remarks: Systematics and evolution of centrospermous families. Plant Syst. Evol. 126:99-106.

Gazula, A., M.D. Kleinhenz, J.C. Scheerens, and P.P. Ling. 2007. Anthocyanin levels in nine lettuce (Lactuca sativa) cultivars: Influence of planting date and relations among analytic, instrumented, and visual assessments of color. HortScience 42:232-238.

Giusti, M.M., L.E. Rodríguez-Saona, and R.E. Wrolstad. 1999. Molar absorptivity and color characteristics of acylated and non-acylated pelargonidin-based anthocyanins. J. Agr. Food Chem. 47:46314637.

Hansen, C.W. and K.L. Nielsen. 2001. Reduced phosphorus availability as a method to reduce chemical growth regulation and to improve plant quality, p. 314-315. In: W.J. Horst, M.K. Schenk, A. Bürkert, N. Claassen, H. Flessa, W.B. Frommer, H. Goldbach, H. Olfs, V. Römheld, B. Sattelmacher, U. Schmidhalter, S. Schubert, N. von Wirén, and L. Wittenmayer (eds.). Plant nutrition-Food security and sustainability of agro-ecosystems. Springer, Dordrecht, The Netherlands.

Hatier, J.H.B. and K.S. Gould. 2009. Anthocyanin function in vegetative organs, p. 1-19. In: K. Gould, K.M. Davies, and C. Winefield (eds.). Anthocyanins: Biosynthesis, functions, and applications. Springer, New York, NY.

Hayakawa, K. and S. Agarie. 2010. Physiological roles of betacyanin in a halophyte, Suaeda japonica Makino. Plant Prod. Sci. 13:351359.

Henry, A., J.P. Lynch, D.G. Clark, and S. Chopra. 2012. Responses to low phosphorus in high and low foliar anthocyanin coleus (Solenostemon scutellarioides) and maize (Zea mays). Funct. Plant Biol. 39(3):255-265.

Henry, J.B., I. McCall, B. Jackson, and B.E. Whipker. 2017. Growth response of herbaceous ornamentals to phosphorus fertilization. HortScience 52:1362-1367.

Henry, J.B., I. McCall, and B.E. Whipker. 2018. Phosphorus restriction as an alternative to chemical plant growth retardants in angelonia and new guinea impatiens. Hort Technology 28:136-142.

Hernández, I. and S. Munné-Bosch. 2015. Linking phosphorus availability with photo-oxidative stress in plants. J. Expt. Bot. 66:2889-2900.

Hlavinka, J., J. Nauš, and M. Špundová. 2013. Anthocyanin contribution to chlorophyll meter readings and its correction. Photosynth. Res. 118:277-295.

Jain, G. and K.S. Gould. 2015a. Are betalain pigments the functional homologues of anthocyanins in plants? Environ. Expt. Bot. 119:4853.

Jain, G. and K.S. Gould. 2015b. Functional significance of betalain biosynthesis in leaves of Disphyma australe under salinity stress. Environ. Expt. Bot. 109:131-140.

Justice, A. and J.E. Faust. 2015. Phosphorus-restriction as a potential technique to control Impatiens stem elongation. Acta Hort. 1104:914.

León, A.P., S.Z. Viña, D. Frezza, A. Chaves, and A. Chiesa. 2007. Estimation of chlorophyll contents by correlations between SPAD502 meter and chroma meter in butterhead lettuce. Commun. Soil Sci. Plant Anal. 38:2877-2885.

Lev-Yadun, S. and K.S. Gould. 2009. Role of anthocyanins in plant defense, p. 21-48. In: K. Gould, K.M. Davies, and C. Winefield (eds.). Anthocyanins: Biosynthesis, functions, and applications. Springer, New York, NY.

Li, G., D. Aubrey, and H. Sun. 2017. Predictive capability of a leaf optical meter for determining leaf pigment status during senescence. Photosynthetica 55:543-552.
Madeira, A.C., A. Ferreira, A. de Varennes, and M.I. Vieira. 2003. SPAD meter versus tristimulus colorimeter to estimate chlorophyll content and leaf color in sweet pepper. Commun. Soil Sci. Plant Anal. 34:2461-2470.

Majsztrik, J.C. and J.D. Lea-Cox. 2013. Water quality regulations in the Chesapeake Bay: Working to more precisely estimate nutrient loading rates and incentivize best management practices in the nursery and greenhouse industry. HortScience 48:1097-1102.

Manetas, Y., G. Grammatikopoulos, and A. Kyparissis. 1998. The use of the portable, non-destructive, SPAD-502 (Minolta) chlorophyll meter with leaves of varying trichome density and anthocyanin content. J. Plant Physiol. 153:513-516.

Marconi, D. and P. Nelson. 1984. Leaching of applied phosphorus in container media. Scientia Hort. 22:275-285.

McGuire, R.G. 1992. Reporting of objective color measurements. HortScience 27:1254-1255.

Mengel, K., E.A. Kirkby, H. Kosegarten, and T. Appel. 2001. Principles of plant nutrition. 5th ed. Kluwer Academic Publishers, Dordrecht, The Netherlands.

Mosse, B. 1973. Plant growth responses to vesicular-arbuscular mycorrhiza. New Phytol. 72:127-136.

Nakashima, T., T. Araki, and O. Ueno. 2011. Photoprotective function of betacyanin in leaves of Amaranthus cruentus L. under water stress. Photosynthetica 49:497-506.

PanAmerican Seed Co. 2017. GrowerFacts. Alternanthera 'Purple Prince' (Alternanthera brasiliana). Ball Horticultural Co., West Chicago, IL.

Plaxton, W.C. and M.C. Carswell. 1999. Metabolic aspects of the phosphate starvation response in plants, p. 350-370. In: H.R. Lerner (ed.). Plant responses to environmental stresses: From phytohormones to genome reorganization. Marcel Dekker, New York, NY.

Polturak, G. and A. Aharoni. 2018. "La Vie En Rose": Biosynthesis, sources, and applications of betalain pigments. Mol. Plant 11:7-22.

Rajendran, L., G. Ravishankar, L. Venkataraman, and K. Prathiba. 1992. Anthocyanin production in callus cultures of Daucus carota as influenced by nutrient stress and osmoticum. Biotechnol. Lett. 14:707-712.

Sarker, B.C. and J. Karmoker. 2011. Effects of phosphorus deficiency on accumulation of biochemical compounds in lentil (Lens culinaris Medik.). Bangladesh J. Bot. 40:23-27.

Sepúlveda-Jiménez, G., P. Rueda-Benítez, H. Porta, and M. RochaSosa. 2004. Betacyanin synthesis in red beet (Beta vulgaris) leaves induced by wounding and bacterial infiltration is preceded by an oxidative burst. Physiol. Mol. Plant Pathol. 64:125-133.

Shin, K., H. Murthy, J. Heo, and K. Paek. 2003. Induction of betalain pigmentation in hairy roots of red beet under different radiation sources. Biol. Plant. 47:149-152.

Silva, N.C.B., A.F. Macedo, C.L.S. Lage, M.A. Esquibel, and A. Sato. 2005. Developmental effects of additional ultraviolet a radiation, growth regulators and tyrosine in Alternanthera brasiliana (L.) Kuntze cultured in vitro. Braz. Arch. Biol. Technol. 48:779-786.

Stagnari, F., A. Galieni, S. Speca, and M. Pisante. 2014. Water stress effects on growth, yield and quality traits of red beet. Scientia Hort. 165:13-22.

Tanaka, Y., N. Sasaki, and A. Ohmiya. 2008. Biosynthesis of plant pigments: Anthocyanins, betalains and carotenoids. Plant J. 54:733-749. Ulrychová, M. and V. Sosnová. 1970. Effect of phosphorus deficiency on anthocyanin content in tomato plants. Biol. Plant. 12:231-235.

Vogt, T., M. Ibdah, J. Schmidt, V. Wray, M. Nimtz, and D. Strack. 1999. Light-induced betacyanin and flavonol accumulation in bladder cells of Mesembryanthemum crystallinum. Phytochemistry 52:583-592.

von Elbe, J.H. 2001. Spectrophotometric determination of betacyanins and betaxanthins. p. F3.1.1-F3.1.2. In: Current protocols in food analytical chemistry. Wiley, New York, NY. 